\title{
Relevansi Kewajiban Ingkar Notaris dalam Menjalankan Jabatannya (Analisis Pasal 16 Huruf f Undang-Undang Nomor 2 Tahun 2014 tentang Perubahan Atas Undang-Undang Nomor 30 Tahun 2004 tentang Jabatan Notaris)
}

\author{
Moh. Sodiq \\ Magister Kenotariatan Universitas Islam Indonesia \\ Jl. Kaliurang KM 16, Kledokan, Umbulmartani, Ngemplak, Sleman \\ sodiqm56@yahoo.com
}

\begin{abstract}
This study aimed to analyze the relevance and role of the notary reneges obligation MKN in providing protection to the contents secret Notary Deed related liabilities. This research is a normative approach to law(statute approach). The data used is secondary data in the form of primary legal materials, secondary law and tertiary legal materials. The results showed that the notary broken instrument liabilities as obligations mentioned in the Act, so that the obligations inherent in the task reneges notary office. MKN established to carry out the functions do coaching in order to maintain the dignity and honor of the Notary in carrying out his profession and provide protection associated with the obligation to keep the contents of the Notary Deed.
\end{abstract}

Keywords: Liability dissenter, notaries, notary honorary council, UUJN-P

\begin{abstract}
Abstrak
Penelitian ini bertujuan untuk menganalisis relevansi kewajiban ingkar notaris dan peran MKN dalam memberikan perlindungan kepada Notaris terkait kewajiban merahasiakan isi Akta. Penelitian ini merupakan penelitian normative dengan pendekatan perundang-undangan (statute approach). Data yang digunakan adalah data sekunder yang berupa bahan hukum primer, bahan hukum sekunder dan bahan hukum tersier. Hasil penelitian menunjukkan bahwa Instrumen kewajiban ingkar notaris sebagai kewajiban yang disebutkan dalam Undang-undang, sehingga kewajiban ingkar notaris melekat pada tugas jabatannya. MKN dibentuk untuk menjalankan fungsi melakukan pembinaan dalam rangka menjaga martabat dan kehormatan Notaris dalam menjalankan profesi jabatannya dan memberikan perlindungan terkait dengan kewajiban Notaris untuk merahasiakan isi Akta.
\end{abstract}

Kata-Kata Kunci: Kewajiban ingkar, notaris, majelis kehormatan notaris, UUJN-P 


\section{Pendahuluan}

Negara adalah suatu organisasi yang memiliki tujuan. Pada konteks Negara Indonesia, tujuan Negara tertuang dalam alenia ke-empat pembukaan UUD 1945, yang mengidentifikasikan bahwa Indonesia merupakan Negara hukum yang menganut konsep welfare state (Negara kesejahteraan). Sebagai Negara hukum yang bertujuan mewujudkan kesejahteraan umum, setiap kegiatan disamping harus diorientasikan pada tujuan yang hendak dicapai juga harus berdasarkan pada hukum yang berlaku sebagai aturan kegiatan kenegaraan, pemerintahan, kemasyarakatan. ${ }^{1}$

Landasan filosofis dibentuknya Undang-undang Jabatan Notaris adalah guna terwujudnya kepastian hukum, ketertiban dan perlindungan hukum yang berintikan kebenaran dan keadilan, melalui akta yang dibuatnya, maka Notaris harus dapat memberikan perlindungan hukum kepada para pihak manapun yang berkepeningan terhadap akta tersebut mengenai kepastian peristiwa atau perbuatan hukum itu dilakukan.

Pasal 1 angka 1 Undang-undang Nomor 2 Tahun 2014 Tentang Perubahan Atas Undang-undang Nomor 30 Tahun 2004 Tentang Jabatan Notaris (selanjutnya disebut dengan UUJN-P) menyatakan bahwa "Notaris adalah pejabat umum yang berwenang untuk membuat akta autentik dan memiliki kewenangan lainnya sebagaimana dimaksud dalam Undang-undang ini atau berdasarkan Undang-undang lainnya.”

Akta autentik dalam bahasa Inggris, disebut dengan authentic deed, sedangkan dalam bahasa Belanda, disebut dengan authentieke akte van, diaur dalam pasal $1868 \mathrm{Kitab}$ Undang-undang Hukum Perdata (selanjutnya disebut dengan KUHPerdata) dan berbagai peraturan perundang-undangan lainnya. ${ }^{2}$

Uraian tersebut di atas menunjukkan bahwa, akta autentik sebagai alat bukti terkuat dan terpenuh mempunyai peranan penting dalam setiap hubungan hukum dalam kehidupan masyarakat. Dalam berbagai hubungan bisinis, kegiatan perbankan dan sebagainya, kebutuhan akan pembuktian tertulis berupa akta autentik makin meningkat sejalan dengan berkembangnya tuntutan akan kepastian hukum dalam berbagai hubungan ekonomi dan sosial. Melalui akta autentik ditentukan secara jelas hak dan kewajibannya, menjamin kepastian hukum dan sekaligus diharapkan dapat mengindari terjadinya sengketa.

${ }^{1}$ Juniarso Ridwan dan Achmad Sodik Sudrajat, Hukum Administrasi Negara dan Kebijakan Pelayanan Publik, (Bandung: NUANSA, 2010), Hlm. 11

2 Salim, HS., Tekbnik Pembuatan Akta Satu (Konsep Teoretis, Kewenagan Notaris, Bentuk, dan Minuta Akta), (Jakarta: Rajagrafindo Persada, 2015), hlm. 17. 
Notaris menyandang suatu etika profesi dimana etika profesi merupakan etika moral yang khusus diciptakan untuk kebaikan jalannya profesi yang bersangkutan, karena setiap profesi mempunyai identitas, sifat atau ciri dan standar profesi sendiri sesuai dengan kebutuhan profesi masing-masing. ${ }^{3}$

Pada pelaksanaannya ditemukan bahwa notaris dalam menjalankan jabatannya, yang berhubungan dengan pembuatan akta, yang menimbulkan permasalahan, mengharuskan seorang notaris dipanggil sebagai saksi oleh aparat penegak hukum dalam hubungannya terkait tugas dan jabatnnya tersebut, hal ini menimbulkan sebuah problematika sendiri bagi notaris, di satu sisi notaris wajib menjaga kerahasiaan atas akta yang dibuatnya, disatu sisi ia berperan sebagai saksi oleh penegak hukum, terlebih negara Indonesia mengaut asas Equality Before the Law (Persamaan dimata hukum). ${ }^{4}$ Aparat penegak hukum di Indonesia tersiri atas, Polisi, Halim, Jaksa, Advokat.

Kewenangan dalam memberikan persetujuan pemanggilan terhadap notaris, yang dipanggil oleh penegak hukum, yang dahulu wewenang dari Majelis Pengawas Notaris, berdasarkan Putusan Mahkamah Konstitusi Nomor 49/PUU-X/2012, tidak bisa dilaksanakan lagi oleh Majelis Pengawas Daerah. Undang-undang Nomor 2 Tahun 2014 ini disahkan frase mendapatkan persetujuan tersebut kembali muncul di dalam Pasal 66 dengan lembaga yang berbeda yaitu majelis kehormatan notaris. Berdasarkan perubahan Pasal 66 UUJN-P tersebut dimana kewenangan majelis pengawas daerah dalam memberikan persetujuan terhadap pemeriksaan notaris oleh penegak hukum tidak berlaku lagi dan menjadi kewenangan majelis kehormatan notaris sesuai dengan Pasal 66 UUJN-P.

Pasal 66:

(1) Untuk kepentingan proses peradilan, penyidik, penuntut umum, atau hakim dengan persetujuan majelis kehormatan Notaris berwenang:

a. mengambil fotokopi Minuta Akta dan/atau surat-surat yang dilekatkan pada Minuta Akta atau Protokol Notaris dalam penyimpanan Notaris; dan

b. memanggil Notaris untuk hadir dalam pemeriksaan yang berkaitan dengan Akta atau Protokol Notaris yang berada dalam penyimpanan Notaris.

Pasal 66A mengatur secara khusus mengenai sebuah lembaga baru yaitu Majelis Kehormatan Notaris. Majelis Kehormatan Notaris merupakan lembaga pembinaan terhadap

\footnotetext{
${ }^{3}$ Muhammad Erwin dan Amrullah Arpan, Filsafat Hukum: Mencari Hakikat Hukum, (Palembang: Universitas Sriwijaya, 2008), hlm. 226.

${ }^{4}$ Asas equality Before the Law, tertuang dalam Pasal 27 ayat (1) UUD 1945 yang berbunyi "Segala warga negara bersama kedudukannya di dalam hukum dan pemerintahan dan wajib menjunjung hukum dan pemerintahan itu dengan tidak ada kecualinya."
} 
notaris yang sebelumnya ada pada majelis pengawas daerah. Jumlah anggota notaris adalah 3 (tiga) orang, pemerintah 2 (dua) orang, dan ahli atau akademisi sebanyak 2(dua) orang. Dalam pembinaan ini unsur notaris lebih banyak dibanding unsur pemerintah dan ahli atau akademisi, karena dalam proses pembinaan notaris lebih mengetahui profesinya. Dalam Peraturan Menteri Hukum dan Hak Asasi Manusia Republik Indonesia Nomor : M.02.PR.08.10 Tahun 2004 tentang Tata Cara Pengangkatan Anggota, Pemberhentian Anggota, Susunan Organisasi, Tata Kerja, dan Tata Cara Pemeriksaan Majelis Pengawas Notaris, pengawasan adalah kegiatan yang bersifat preventif dan represif termasuk kegiatan pembinaan yang dilakukan oleh majelis pengawas terhadap notaris. ${ }^{5}$

Selain Pasal 66 UUJN-P yang mengatur kewenangan Majelis Kehormatan notaris dalam memberikan perlindungan terhadap notaris, dalam Pasal 16 ayat (1) huruf $f$ UUJN-P merupakan bentuk perlindungan terhadap notaris dalam menjalankan jabatannya, yakni notaris wajib "merahasiakan segala sesuatu mengenai akta yang dibuatnya dan segala keterangan yang diperoleh guna pembuatan akta sesuai dengan sumpah/janji jabatan, kecuali undang-undang menentukan lain."

Penjelasannya bahwa Kewajiban untuk merahasiakan segala sesuatu yang berhungungan dengan akta dan surat-surat lainnya adalah untuk melindungi kepentingan sesama pihak yang terkait dengan akta tersebut. Pasal 54 UUJN bahwa "Notaris hanya dapat memberikan, memperlihatkan, atau memberitahukan isi akta, grosse akta, salinan akta atau kutipan akta, kepada orang yang berkepentingan langsung pada akta, ahli waris, atau orang yang memperoleh hak, kecuali ditentukan lain oleh peraturan perundang-undangan”. UUJN telah menempatkan Kewajiban Ingkar Notaris sebagai suatu Kewajiban Notaris, artinya sesuatu yang harus dilaksanakan tanpa alasan apapun.

Kewajiban merahasiakan segala sesuatu yang berhungungan dengan akta dan suratsurat lainnya yang diatur dalam UUJN sebagai Lex Specialis nya, selain itu dalam Pasal 170 Kitab Undang-undang Hukum Acara Pidana menyatakan: 1) "Mereka yang pekerjaan, harkat, martabat atau jabatannya diwajibkan menyimpan rahasia dapat minta dibebaskan dari kewajiban untuk memberi keterangan sebagai saksi, yaitu tentang hal dipercayakan kepada mereka." 2. "Hakim menentukan sah atau tidaknya segala alasan untuk permintaan tersebut."

Berdasarkan latar belakang tersebut di atas, maka peneliti tertarik untuk meneliti mengenai Relevansi Kewajiban Ingkar Notaris Dalam Menjalankan Jabatannya (Analisis

${ }^{5}$ Ineke Bombing, Pengawasan Terhadap Pejabat Notaris Dalam Pelanggaran Kode Etik, jurnal, Lex Privatum, Vol. III/No. 2/Apr-Jun/2015, Hlm. 110. 
Pasal 16 Huruf f Undang-undang Nomor 2 Tahun 2014 Tentang Perubahan Atas Undangundang Nomor 30 Tahun 2004 Tentang Jabatan Notaris).

\section{Rumusan Masalah}

Berangkat dari uraian di atas, maka rumusan masalah dalam penelitian ini adalah bagaimana relevansi kewajiban ingkar notaris dalam menjalankan jabatannya berdasarkan Pasal 16 ayat (1) huruf f UUJN-P? dan bagaimana peran Majelis Kehormatan Notaris dalam memberikan perlindungan kepada Notaris terkait dengan kewajiban untuk merahasiakan isi Akta?

\section{Tujuan penelitian}

Penelitian ini bertujuan untuk menemukan dan menganalisis relevansi kewajiban ingkar notaris dalam menjalankan jabatannya berdasarkan UUJN-P dan menganalisa peran Majelis Kehormatan Notaris dalam memberikan perlindungan kepada Notaris terkait dengan kewajiban untuk merahasiakan isi Akta.

\section{Metode Penelitian}

Penelitian ini merupakan penelitian normatif karena menggunakan bahan kepustakaan atau penelitian pustaka (library research). Data yang digunakan adalah data sekunder yang berupa bahan hukum primer yang meliputi (a) Undang-undang Nomor 2 Tahun 2014 yang merupakan perubahan atas Undang-undang Nomor 30 Tahun 2004 Tentang Jabatan Notaris, (b) Kode Etik Notaris, (c) Kitab Undang-undang Hukum Perdata. Bahan hukum sekunder, yang terdiri dari buku-buku literatur, hasil penelitian dan karya ilmiah lainnya yang berhubungan dengan topik penelitian ini. Selain itu, terdapat juga dokumen hasil wawancara dengan pakar-pakar hukum dan politik. 3) Bahan hukum tersier, yang terdiri dari: a. Kamus Umum Bahasa Indonesia; b. Kamus Inggris - Indonesia; c. Kamus Istilah Hukum; d. Ensiklopedia. Metode pendekatan yang digunakan adalan pendekatan perundang-undangan (statute approach). Bahan hukum yang terkumpul dianalisis secara kualitatif dan disajikan dalam bentuk deskriptif. 


\section{Hasil Penellitian dan Pembahasan}

\section{Relevansi Kewajiban Ingkar Notaris Dalam Menjalankan Jabatannya Berdasarkan UUJN-P.}

Relevansi menurut Kamus Besar Bahasa Indonesia, ${ }^{6}$ berarti keterkaitan, hubungan. Sedangkan kewajiban menurut Kamus Besar Bahasa Indonesia, diartikan sebagai sesuatu yang diwajibkan, sesuatu yang dilaksanakan atau dapat dilaksanakan atau dapat diartikan juga sebagai suatu keharusan. Sehingga kewajiaban notaris adalah sesuatu yang harus dilaksanakan oleh notaris dalam menjalankan jabatannya, karena menjadi suatu keharusan yang diharuskan oleh UUJN.

Bagian dari sumpah/janji notaris yaitu bahwa notaris akan merahasiakan isi akta dan keterangan yang diperoleh dalam pelaksanaan jabatan Notaris. ${ }^{7}$ Pasal 16 ayat (1) huruf f UUJN-P menjelaskan, bahwa notaris berkewajiban untuk merahasiakan segala sesuatu yang mengenai akta yang dibuatnya dan segala keterangan yang diperoleh guna pembuatan akta sesuai dengan sumpah/janji jabatan, kecuali Undang-undang menentukan lain. Ketentuan Pasal 16 ayat (1) huruf $f$ UUJN-P ini ditempatkan sebagai kewajiban ingkar notaris.

Notaris wajib merahasiakan isi akta dan keterangan yang diperoleh dalam pembuatan akta notaris, kecuali diperintahkan oleh Undang-undang bahwa notaris tidak wajib merahasiakan dan memberikan keterangan yang diperlukan berkaitan dengan akta tersebut, dengan demikian batansannya hanya Undang-undang saja yang dapat memerintahkan notaris untuk membuka rahasia isi akta dan keterangan/pernyataan yang diketahui notaris yang berkaitan dengan pembuatan akta yang dimaksud. ${ }^{8}$

Substansi sumpah/janji jabatan notaris ataupun Pasal 16 ayat (1) huruf f UUJN-P untuk merahasiakan segala sesuatu yang berkaitan dengan akta yang dibuat atau di hadapan notaris dan berkaitan dengan pelaksanaan tugas jabatan notaris.

Instrumen Kewajiban ingkar notaris ditegaskan sebagai salah satu kewajiban yang disebutkan dalam Pasal 16 ayat (1) huruf f UUJN-P, sehingga kewajiban ingkar untuk notaris melekat pada tugas jabatan notaris. Sebagai suatu kewajiban yang harus dilaksanakan, berbeda dengan hak ingkar yang dapat dipergunakan atau tidak dipergunakan. Tetapi kewajiban ingkar mutlak dilakukan dan dijalankan oleh notaris, kecuali ada Undangundang yang memerintahkan untuk menggugurkan kewajiban ingkar tersebut.

\footnotetext{
${ }^{6}$ www.kbbi.web.id diakses pada tanggal 9 Desember 2016

7 Pasal 4 ayat (2) UUJN

${ }^{8}$ Habib Adjie, Hukum Notaris Indonesia Tafsir..... hlm. 89
} 
Peraturan perundang-undangan yang menggugurkan atau memberikan batasan mengenai kewajiban dalam merahasiakan atau menggunakan kewajiban ingkarnya, yaitu:

a. Pasal 25 ayat (1) Undang-undang Nomor 20 Tahun 2000 tentang BPHTB.

b. Pasal 36 Undang-undang Nomor 31 Tahun 1999 yang telah diubah dalam Undangundang Nomor 20 Tahuhn 2001 tentang Pemberantasan Tindak Pidana Korupsi. ${ }^{9}$

c. Pasal 19 ayat (2) Undang-undang Darurat Republik Indonesia Nomor 7 Tahun 1955 tentang Pengusutan, Penuntutan, dan Peradilan Tindak Pidana Ekonomi. ${ }^{10}$

d. Pasal 35 ayat (2) Undang-undang Nomor 28 Tahun 2007 tentang perubahan atas Undangundang Nomor 6 Tahun 1983 tentang Ketentuan Umum dan Tata Cara Perpajakan.

Notaris adalah jabatan kepercayaan (vertrouwens ambt) dan oleh karenanya seseorang bersedia mempercayakan kepadanya sebagai seorang kepercayaan (vertrouwens persoon). Notaris wajib merahasiakan semua apa yang diberitahukan kepadanya selaku notaris sekalipun ada sebagian yang tidak dicantumkan dalam akta. ${ }^{11}$

Dengan adanya peraturan perundang-undangan yang mengatur mengenai keharusan atau kewajiban merahasiakan isi akta sesuai dengan jabatan, maka pihak penegak hukum lain yang untuk kepentingan proses peradilan, penyidik ${ }^{12}$, penuntut umum, atau hakim dengan meminta persetujuan dari Majelis Kehormatan Notaris, berwenang: a. Mengambil fotokopi minuta akta/surat-surat yang dilekatkan pada minuta akta atau protokol notaris daslam penyimpanan notaris. b. Memanggil notaris untuk hadir dalam pemeriksaan yang berkaitan dengan akta atau protokol notaris yang berada dalam penyimpanan notaris.

Kewajiban Ingkar dapat dilakukan dengan batasan sepanjang notaris yang diperiksa oleh instansi mana saja yang berupaya meminta pernyataan atau keterangan dari notaris yang berkaitan dengan akta yang telah atau dibuat oleh atau di hadapan notaris yang bersangkutan.

Pasal 1909 ayat (3) KUHPerdata menyebutkan: "Semua orang yang cakap untuk menjadi saksi, wajib memberikan kesaksian di muka Hakim. Namun dapatlah meminta dibebaskan dari kewajiban memberikan kesaksian; Ayat (3) siapa saja yang karena kedudukannya, pekerjaannya atau jabatannya diwajibkan undang-undang untuk

\footnotetext{
${ }^{9}$ Lihat Pasal 36 Undang-undang Nomor 31 Tahun 1999 yang telah diubah dalam Undang-undang Nomor 20 Tahuhn 2001 tentang Pemberantasan Tindak Pidana Korupsi.

${ }^{10}$ Lihat Pasal 19 ayat (2) Undang-undang Darurat Republik Indonesia Nomor 7 Tahun 1955 tentang Pengusutan, Penuntutan, dan Peradilan Tindak Pidana Ekonomi.

11 Sjaifurahman dan Habib Adjie, Aspek Pertanggungjawaban Notaris Dalam pembuatan Akta, (Bandung: Mandar Maju, 2011), hlm. 252-253.

12 Pasal 1 angka 1 Undang-undang Kepolisian, penyidik adalah polisi Negara Republik Indonesia atau pegawai negeri sipil tertentu yang diberi kewenangan khusus oleh undang-undang untuk melakukan penyelidikan.
} 
merahasiakan sesuatu, namun hanya mengenai hal-hal yang dipercayakan kepadanya karena kedudukan, pekerjaan dan jabatannya itu."

Pasal 146 ayat (1) angka 3 HIR menyebutkan: (1) "Boleh mengundurkan dirinya untuk memberikan kesaksian, sekalian orang yang karena martabatnya, pekerjaan atau jabatan yang sah diwajibkan menyimpan rahasia, akan tetapi hanya semata-mata mengenai pengetahuan yang diserahkan kepadanya karena martabat, pekerjaan atau jabatannya itu." (2) Kesungguhan kewajiban menyimpan rahasia yang dikatakan itu, terserah dalam pertimbangan Pengadilan Negeri."

Keharusan untuk merahasiakan sesuatu yang berkaitan dengan jabatan diatur pula dalam Kitab Undang-Undang Hukum Acara Pidana, yakni Pasal 170 ayat (1) yang menyatakan bahwa, mereka yang karena pekerjaan, harkat, martabat, atau juga jabatannya diwajibkan untuk menyimpan rahasia, dapat minta dibebaskan dari penggunaan hak untuk memberikan keterangan sebagai saksi, yaitu tentang hal yang dipercayakan kepadanya. ${ }^{13}$

Notaris sebagai jabatan kepercayaan wajib untuk menyimpan rahasia mengenai akta yang dibuatnya dan keterangan/pernyataan para pihak yang diperoleh dalam pembuatan akta, kecuali Undang-undang yang memerintahkannya untuk membuka rahasia dan memberikan keterangan/pernyataan tersebut kepada pihak yang memintanya. Tindakan seperti ini merupakan suatu kewajiban notaris berdasarkan ketentuan Pasal 4 ayat (2) dan Pasal 16 ayat (1) huruf f UUJN-P. Jika ternyata notaris sebagai saksi atau tersangka, tergugat ataupun dalam pemeriksaan oleh Majelis Kehormatan Notaris (MKN) Notaris membuka rahasia dan memberikan keterangan/pernyataan yang seharusnya wajib dirahasiakan, sedangkan Undang-undang tidak memerintahkannya, maka atas pengaduan pihak yang merasa dirugikan kepada pihak yang berwajib dapat diambil tindakan atas notaris tersebut, tindakan notaris seperti ini dapat dikenakan sanksi pidana yang terdapat pada Pasal 322 ayat (1) dan ayat (2) KUHP yang berbunyi:

“Ayat (1) Barang siapa dengan sengaja membuka rahasia yang wajib disimpannya karena jabatan atau pencahariannya, baik yang sekarang maupun yang dahulu, diancam dengan pidana penjara paling lama Sembilan bulan atau pidana denda paling banyak Sembilan ribu rupiah."

"Ayat (2) Jika kejahatan dilakukan terhadap seorang tertentu, maka perbuatan itu hanya dapat dituntut atas pengaduan orang itu."

Dengan demikian, bagian dari sumpah/janji jabatan notaris yang berisi bahwa notaris akan merahasiakan isi akta dan keterangan yang diperoleh dalam pelaksanaan jabatan

${ }^{13}$ Lihat Pasal 170 ayat (1) KUHAP 
notaris dan dikaitkan dengan ketentuan Pasal 16 ayat (1) huruf f UUJN-P karena ditempatkan sebagai kewajiban ingkar notaris dapat disebut sebagai suatu kewajiban ingkar (Verschoningsplicht) notaris. ${ }^{14}$

Oleh karena itu, agar notaris dapat memberikan pelayanan jasa secara maksimal serta menghasilkan produk akta yang benar-benar terjaga otentisitasnya sehingga memiliki nilai dan bobot yang handal, serta tidak menimbulkan kerugian bagi diri notaris dan masyarakat yang membutuhkan jasanya, maka notaris harus mengindahkan yang menjadi tugas dan kewajiban yang diamanatkan baik oleh UUJN, Kode Etik Notaris maupun perundangundangan yang terkait, serta menghindari larangan-larangan yang telah ditentukan. Dengan demikian dapat dikatakan bahwa terdapat hubungan yang saling melengkapi antara UUJN dan Kode Etik dalam mengatur ketentuan tentang kewajiban dan larangan serta pengecualian dalam jabatan Notaris.

\section{Peran Majelis Kehormatan Notaris Dalam Memberikan Perlindungan Kepada Notaris Terkait Kewajiban Merahasiakan Isi Akta}

\section{Majelis Kehormatan Notaris Pasca UUJN-P}

Sejak kehadiran institusi notaris di Indonesia pengawasan terhadap notaris selalu dilakukan oleh lembaga peradilan dan pemerintah, bahwa tujuan dari pengawasan agar para notaris ketika menjalankan tugas jabatannya memenuhi semua persyaratan yang berkaitan dengan pelaksanaan jabatan notaris, demi pengamanan dari kepentingan masyarakat, karena notaris diangkat oleh pemerintah, dalam hal ini Menteri Hukum dan HAM, bukan untuk kepentingan diri notaris sendiri, tetapi untuk kepentingan masyarakat yang dilayaninya.

Tujuan lain dari pengawasan terhadap notaris, bahwa notaris dihadirkan untuk melayani kepentingan masyarakat yang membutuhkan alat bukti berupa akta autentik sesuai permintaan yang bersangkutan kepada notaris, dalam hal ini pengawasan terhadap notaris

${ }^{14}$ Diakuinya hak ingkar sebagai imunitas hukum untuk kewajiban member keterangan sebagai saksi di penagdilan, bagi jabatan-jabatan tertentu, antara lain Notaris, atas dasar:

a. Pasal 179 Kitab Undang-undang Hukum Acara Pidana (KUHAP)

b. Pasal 1909 ayat (3) Kitab Undang-undang Hukum Perdata (KUHPerdata)

c. Pasal 40 jo. Pasal 17 PJN

d. Pasal 146 ayat (1) angka 3 HIR.

e. Pasal 277 HIR

Paulus Efendi Lotulung..., Loc. Cit., Hlm. 6 
dilakukan oleh Majelis Pengawasa Notaris, ${ }^{15}$ sedangkan pembinaan terhadap Notaris dalam hal ini dilakukan oleh Majelis Kehormatan Notaris. ${ }^{16}$

Kewenangan untuk melakukan pemanggilan terhadap notaris sebelum berlakunya UUJN-P, yaitu terdapat pada Pasal 66 ayat (1) Undang-undang Nomor 30 Tahun 2004 Tentang Jabatan Notaris, yang berbunyi: Untuk kepentingan proses peradilan, penyidik, penuntut umum, atau hakim dengan persetujuan Majelis Pengawas Daerah berwenang:

a. Mengambil fotokopi minuta akta/surat-surat yang dilekatkan pada minuta akta atau protokol notaris daslam penyimpanan notaris.

b. Memanggil notaris untuk hadir dalam pemeriksaan yang berkaitan dengan akta atau protokol notaris yang berada dalam penyimpanan notaris.

Akan tetapi setelah keluar Putusan Mahkamah Konstitusi Nomor 49/PUU-X/2012 tertanggal 28 Mei 2013 saat itu yang menghapus hak istimewa Notaris dalam memberikan keterangan kepada polisi. Dengan kata lain berdasarkan Putusan MKRI tersebut, untuk kepentingan proses peradilan, Penyidik, Penuntut Umum, atau Hakim, berwenang : a. Mengambil fotokopi minuta akta dan/atau surat-surat yang dilekatkan pada minuta akta atau protokol Notaris dalam penyimpanan Notaris; dan b. Memanggil Notaris untuk hadir dalam pemeriksaan yang berkaitan dengan akta yang dibuatnya atau protokol Notaris yang berada dalam penyimpanan Notaris.

\section{Pasca putusan MK Nomor 49/PUU-X/2012}

Setelah MK membatalkan frasa "sakti" tersebut, notaris masih tetap memiliki kewajiban ingkar berkaitan dengan rahasia yang wajib dijaga. Berdasarkan Pasal 16 ayat (1) huruf e UUJN menyatakan bahwa, notaris berkewajiban merahasiakan segala sesuatu mengenai akta yang dibuatnya dan segala keterangan yang diperoleh guna pembuatan akta sesuai dengan sumpah/janji jabatan, kecuali Undang-undang menentuan lain.

Tanpa persetujuan Majelis Pengawas Daerah (MPD) atau MPD sudah tidak mempunyai kewenangan apapun yang berkaitan dengan Pasal 66 ayat (1) UUJN. Sehingga jika Penyidik, Penuntut Umum dan Hakim akan melaksanakan ketentuan yang tersebut dalam Pasal 66 UUJN terhadap Notaris, maka Notaris harus berhadapan langsung dengan Penyidik, Penuntut Umum dan Hakim. ${ }^{17}$ hlm. 3 .

${ }^{15}$ Habib Adjie, Majelis Pengawas Notaris Sebagai Pejabat Tata Usaha Negara, (Bandung: Refika Aditama, 2010),

${ }^{16}$ Lihat Permenkumham Nomor 7 Tahun 2016 Tentang Majelis Kehormatan Notaris.

${ }^{17}$ Habib Adjie, Memahami Hak Ingkar dan Kewajiban Ingkar Notaris. 
Zul Fadli berpendapat bahwa ada yang beranggapan putusan ini memang sudah seharusnya dan ada pula yang berkomentar putusan ini sebagai mala petaka atau langkah mundur bagi profesi notaris. ${ }^{18}$

Putusan Mahkamah Konstitusi tersebut tidak dapat digunakan lagi setelah lahirnya Undang-undang Nomor 2 Tahun 2014 yang merupakan perubahan atas Undang-undang Nomor 30 Tahun 2004 Tentang Jabatan Notaris, karena diantara pasal 66 dan 67 UUJN-P terdapat tambahan, yaitu Pasal 66A yang mengatur Mengenai persetujuan dari Majelis Kehormatan Notaris dalam kepentingan proses peradilan, penyidik, penuntut umum, atau hakim.

Berdasarkan Pasal 66A ayat (3) Undang-undang Nomor 2 Tahun 2014 yang merupakan perubahan atas Undang-undang Nomor 30 Tahun 2004 tentang Jabatan Notaris, maka kemudian Menteri Hukum dan Hak Asasi Manusia Republik Indonesia menerbitkan Peraturan Menteri Hukum Dan Hak Asasi Manusia Republik Indonesia (selanjutnya disebut Permenkumham) Nomor 7 Tahun 2016 Tentang Majelis Kehormatan Notaris. Permenkumham tersebut mulai berlaku tanggal diundangkan, yaitu tanggal 5 Pebruari 2016. Dengan demikian sejak tanggal 5 Pebruari 2016, menurut Habib Adjie, jika Penyidik akan memanggil Notaris, maka wajib terlebih dahulu meminta izin dari MKN (Majelis Kehormatan Wilayah) yang ada di wilayah / propinsi yang bersangkutan. Bahwa ketentuan Permenkumham Nomor 7 Tahun 2016 Tentang Majelis Kehormatan Notaris tersebut sifat imperative, artinya harus/wajib dilaksanakan oleh Penyidik, karena jika hal tersebut tidak dilakukan atau diabaikan oleh Penyidik, maka penyidikan bisa dikategorikan dari sisi hukum telah cacat formalitas.

Pengertian Majelis Kehormatan Notaris berdasarkan pasal 1 angka 1 Permenkumham Nomor 7 tahun 2016 Tentang Majelis Kehormatan Notaris, adalah suatu badan yang mempunyai kewenangan untuk melakukan pembinaan Notaris dan kewajiban memberikan persetujuan atau penolakan untuk kepentingan penyidikan dan proses peradilan, atas pengambilan fotokopi minuta akta dan pemanggilan Notaris untuk hadir dalam pemeriksaan yang berkaitan dengan akta atau protokol notaris yang berada dalam penyimpanan Notaris. ${ }^{19}$

${ }^{18}$ Habib Adjie, Muhammad Hafidz, dan Zul Fadli, Himpunan Putusan Mabkamah Konstitusi Republik Indonesia mengenai Undang-Undang Jabatan Notaris (UUJN), (Semarang: Duta Nusindo, 2016), hlm. 1.

${ }_{19}$ Pasal 1 angka 1 Permenkumham Nomor 7 tahun 2016 Tentang Majelis Kehormatan Notaris. 
Ketentuan Pasal 66A UUJN-P menunjuk pada wewenang Majelis Kehormatan Notaris yaitu melakukan pembinaan, perihal wewenang Majelis Kehormatan Notaris melakukan pembinaan diatur dalam Peraturan Menteri Hukum dan Hak Asasi Manusia sebagaimana dimaksud dalam Pasal 66 A ayat (3) UUJN-P, diatur dalam Peraturan Menteri Hukum dan Hak Asasi Manusia, Tugas pembinaan yang dilakukan oleh Majelis Kohormatan Notaris tidak lepas dari pada penegakan Etika Notaris, meliputi norma agama, norma hukum, norma kesusilaan, dan norma kesopanan. Norma agama, norma kesusilaan, dan norma kesopanan berhubungan dengan etika. ${ }^{20}$

Tugas dan fungsi Majelis Kehormatan Notaris, berdasarkaan ketentuan Pasal 17 Permenkumham Nomor 7 Tahun 2016 Tentang Majelis Kehormatan Notaris, yang menyatakan: (1) Majelis Kehormatan Notaris Pusat mempunyai tugas melaksanakan pembinaan terhadap Majelis Kehormatan Wilayah yang berkaitan dengan tugasnya. (2) Dalam melaksanakan tugas sebagaimana dimaksud pada ayat (1), Majelis Kehormatan Notaris Pusat mempunyai fungsi melakukan pengawasan terhadap Majelis Kehormatan Notaris Wilayah.

Majelis Kehormatan Notaris Wilayah dibentuk untuk menjalankan fungsi melakukan pembinaan dalam rangka menjaga martabat dan kehormatan Notaris dalam menjalankan profesi jabatannya dan memberikan perlindungan kepada Notaris terkait dengan kewajiban Notaris untuk merahasiakan isi Akta. Untuk itu Majelis Kehormatan Notaris Wilayah memiliki wewenang, sesuai yang terdapat pada Pasal 18:

(1) Majelis Kehormatan Notaris Wilayah mempunyai tugas:

a) melakukan pemeriksaan terhadap permohonan yang diajukan oleh penyidik, penuntut umum, dan hakim; dan

b) memberikan persetujuan atau penolakan terhadap permintaan persetujuan pemanggilan Notaris untuk hadir dalam penyidikan, penuntutan, dan proses peradilan.

(2) Dalam melaksanakan tugas sebagaimana dimaksud pada ayat (1), Majelis Kehormatan Notaris Wilayah mempunyai fungsi melakukan pembinaan dalam rangka:

a) menjaga martabat dan kehormatan Notaris dalam menjalankan profesi jabatannya;

b) dan memberikan perlindungan kepada Notaris terkait dengan kewajiban Notaris untuk merahasiakan isi Akta.

Kewenangan Majelis Kehormatan Notaris Wilayah berdasarkan Keputusan Rapat Majelis Kehormatan Notaris Wilayah meliputi: ${ }^{21}$

a. pemeriksaan terhadap Notaris yang dimintakan persetujuan kepada Majelis Kehormatan Notaris Wilayah oleh penyidik, penuntut umum, atau hakim;

\footnotetext{
${ }^{20}$ www.indonesianotarycommunity.com, diakses Tanggal 29 Oktober 2016

${ }^{21}$ Lihat Pasal 20 Permenkumham Nomor 7 Tahun 2016 Tentang Majelis Kehormatan Notaris
} 
b. pemberian persetujuan atau penolakan terhadap permintaan persetujuan pengambilan fotokopi minuta akta dan/atau surat-surat yang dilekatkan pada minuta akta atau protokol Notaris dalam penyimpanan Notaris; dan,

c. pemberian persetujuan atau penolakan terhadap permintaan persetujuan pemanggilan Notaris untuk hadir dalam penyidikan, penuntutan, dan proses peradilan yang berkaitan dengan akta atau protocol Notaris yang berada dalam penyimpanan Notaris.

\section{Majelis Kehormatan Notaris sebagai Pejabat Tata Usaha Negara dan Keputusannya sebagai Keputusan Tata Usaha Negara}

Undang-undang Nomor 5 Tahun 1986 tentang Peradilan Tata Usaha Negara, dikenal istilah Badan atau Pejabat Tata Usaha Negara, yaitu Badan atau Pejabat Tata Usaha Negara adalah Badan atau Pejabat yang melaksanakan urusan pemerintahan berdasarkan peraturan perundangundangan yang berlaku ${ }^{22}$ pada saat melaksanakan suatu bidang urusan pemerintahan.

Penjelasan dari Pasal 1 anga 1 Undang-undang Nomor 5 Tahun 1986 tentang Peradilan Tata Usaha Negara tersebut, bahwa yang dimaksud dengan urusan pemerintahan ialah kegiatan yang bersifat eksekutif, dan yang dimaksud dengan pemerintah adalah keseluruhan kegiatan yang menjadi tugas dan dilaksanakan oleh para Badan dan jabatan (pejabat) Tata Usaha Negara (TUN) yang bukan pembuatan peraturan dan mengadili. Pengertian sebagaimana dikemukakan oleh Philipus M. Hadjon, bahwa pemerintah dapat dilihat dari 2 (dua) sudut, yaitu: ${ }^{23}$ a. Pemerintah dalam arti fungsi, yakni kegiatan yang mencakup aktivitas pemerintahan. b. Pemerintahan dalam arti organisasi, yaitu kumpulan dari kesatuan-kesatuan pemerintahan.

Badan atau Pejabat Tata Usaha Negara merupakan unsur pokok dan terbesar dari penguasa diantara sekian banyaknya penyelenggara urusan pemerintah. Sebutan Pejabat Tata Usaha Negara tidak hanya ditujukan kepada mereka yang mempunyai jabatan secara sturuktural, memangku suatu jabatan Tata Usaha Negara, tetapi juga dapat ditujukan kepada siapa saja yang berdasarkan peraturan perundang-undangan melakukan urusan pemerintah (fungsional), maka yang berbuat demikian dapat dianggap sebagai Badan atau Pejabat Tata Usaha Negara, sehingga segala keputusan Tata Usaha Negara, jika merugikan pihak-pihak tertentu, keputusan tersebut dapat dijadikan objek gugatan ke Pengadilan Tata Usaha Negara. ${ }^{24}$

${ }^{22}$ Lihat Pasal 1 angka 1 Undang-undang Nomor 5 Tahun 1986 tentang Peradilan Tata Usaha Negara

${ }^{23}$ Philipus M. Hadjon, dalam H.A. Muin Fahmal, Asas-asas Uimum Pemrintahan yang Layak dalam Mewriudkan Pemerintahan yang Bersih, (Yogyakarta: UII Press, 2006), hlm. 26

${ }^{24}$ Habib Adjie, Majelis Pengawas Notaris,... Op. Cit., Hlm. 39. 
Delegasi merupakan pelimpahan suatu wewenang yang telaha da Badan atau Jabatan Tata Usaha Negara yang telah memperoleh suatu wewenang pemerintahan secara atributif kepada Badan atau Jabatan Tata Usaha Negara lainnya. Dalam rumusan lain bahwa delegasi merupakan penyerahan wewenang oleh pejabat pemerintahan (sebagai Pejabat tata Usaha Negara) kepada pihak lain dan wewenang tersebut menjadi tanggung jawab pihak lain dan wewenang tersebut menjadi tangung jawab pihak lain tersebut. ${ }^{25}$

Pendapat pertama menyatakan, bahwa delegasi itu harus dari badan atau jabatan Tata Usaha Negara kepada badan atau Jabatan Tata Usaha Negara lainnya, artinya baik delegator maupun delegaans harus sama-sama Badan atau Jabatan Tata Usaha Negara. Pendapat yang kedua menyatakan bahwa delegasi dapat terjadi dari badan atau Jabatan Tata Usaha Negara kepada pihak lain yang belum tentu Badan atau Jabatan tata Usaha Negara. Dengan adanya kemungkinan bahwa Badan atau Jabatan Tata Usaha Negara dapat mendelegasikan kewenangannya (delegaans) kepada Badan atau Jabatan bukan Tata Usaha Negara (delegataris). Suatu delegasi selalu didahului oleh adanya suatu atribusi wewenang.

Kedudukan menteri selaku badan atau Jabatan Tata usaha Negara yang melaksanakan urusan pemerintahan berdasarkan peraturan perundang-undangan yang berlaku membawa konsekwensi terhadap Majelis Kehormatan Notaris, yaitu Majelis Kehormatan Notaris Berkedudukan pula sebagai Badan atau jabatan tata Usaha Negara, karena mendrima delegasi dari Badan atau Jabata yang berkedudukan sebagai badan atau Jabatan Tata Usaha Negara. Dengan demikain seara kolegial, Majelis Kehormatan sebagai: a. Badan atau Pejabat tata Usaha Negara; b. Melaksanakan urusan pemerintahan; c. Berdasarkan peraturan perundang-undnagan yang berlaku, yaitu melakukan pembinaan terhadap notaruis sesuai dengan Undang-undang Jabatan Notaris.

Dalam melakukan pembinaan, Majelis Kehormatan Notaris harus berdasarkan ketentuan yang diatur oleh Undang-undang Jabatan Notaris dan Peraturan Menteri Hukum daan Hak Asasi Manusia Nomor 7 Ttahun 2006 Tentang Majelis Kehormatan Notaris, sebagai acuan untuk mengambil keputusan, hal ini perlu dipahami karena anggota Majelis Kehormatan Notaris tidak semua dari Notaris, sehingga tindakan atau keputusan dari Majelis Kehormatan Notaris, harus mencerminkan suatu tindakan Majelis Kehormatan Notaris sebagai suatu Badan, bukan tindakan anggota Majelis Kehormatan yang dianggap sebagai tindakan Majelis Kehormatan.

${ }^{25}$ Philipus M. Hadjon dalam Habib Adjie, Majelis Pengawas notaris...., hlm. 41. 
Bahwa kesimpulannya mengenai pebedaan Majelis Kehormatan Notaris dengan Majelis Pengawas Notaris, Pengawasan notaris dengan membentuk Majelis Pengawas Notaris dan Pembinaan dengan membentuk Majelis Kehormatan Notaris semuanya ada pada kewenangan Menteri Hukum dan HAM RI. Pemerintah atau Menteri adalah Eksekutif yang berarti Tata Usaha Negara, karena Menteri sebagai Pejabat Tata Usaha Negara maka delegansnya yaitu MPN dan MKN juga sebagai Pejabat Tata Usaha Negara, sebagai Pejabat Tata Usaha Negara maka produknya termasuk pada Keputusan Tata Usaha Negara. Jika Keputusan Tata Usaha Negara jadi sengketa, maka akan termasuk Sengketa Tata Usaha Negara yang dapat digugat ke Pengadilan Tata Usaha Negara.

\section{Penutup}

Berdasarkan paparan di atas maka dapat disimpulkan bahwa pertama, Notaris sebagai pejabat publik yang diangkat dan diberhentikan oleh Menteri Hukum dan Hak Asasi Manusia. Notaris sebagai pejabat publik produk akhirnya yaitu akta autentik, yang terikat dalam ketentuan hukum perdata terutama dalam hukum pembuktian. Kewajiban ingkar Notaris merupakan sebuah keharusan yang harus dilakukan oleh notaris berkaitan dengan tugas dan jabatannya. Peraturan perundang-undnagan lainnya juga menghendaki adanya kewajiban ingkar tersebut. Keberadaan Kewajiban ingkar notaris bukanlah suatu alat pelindung bagi notaris untuk bertindak dengan tidak memperhatikan aturan-aturan yang sudah ditentukan, perlindungan yang sebenarnya adalah berasal dari notaris itu sendiri, yaitu dengan cara memperhatikan peraturan perundang-undangan yang terkait serta kode etik jabatan.

Kedua, majelis Kehormatan Notaris berperan untuk melaksanakan pembinaan, kepada notaris. Berlandaskan Pasal 66A Undang-undang Nomor 2 Tahun 2014 Tentang Jabtan Notaris dan Peraturan Menteri Hukum dan Hak Asasi Manusia Nomor 7 Tahun 2016 tentang Majelis Kehormatan Notaris, Majelis Kehormatan Notaris dibentuk untuk menjalankan fungsi melakukan pembinaan dalam rangka menjaga martabat dan kehormatan Notaris dalam menjalankan profesi jabatannya dan memberikan perlindungan kepada Notaris terkait dengan kewajiban Notaris untuk merahasiakan isi Akta.

\section{Daftar Pustaka}

Adjie, Habib, Hukum Notaris Indonesia, Refika Aditama, Bandung, 2008. , Majelis Pengawas Notaris Sebagai Pejabat Tata Usaha Negara, Refika Aditama, Bandung, 2010. 
, Majelis Pengawas Notaris Sebagai Pejabat Tata Usaha Negara, Refika Aditama, Bandung, 2010.

, Memahami Hak Ingkar dan Kewajiban Ingkar Notaris.

, Muhammad Hafidz, dan Zul Fadli, Himpunan Putusan Mahkamah Konstitusi Republik Indonesia mengenai Undang-Undang Jabatan Notaris (UUJN), Duta Nusindo, Semarang, 2016.

Bombing, Ineke, Pengawasan Terhadap Pejabat Notaris Dalam Pelanggaran Kode Etik, jurnal, Lex Privatum, Vol. III/No. 2/Apr-Jun/2015.

Erwin, Muhammad, dan Amrullah Arpan, Filsafat Hukum: Mencari Hakikat Hukum, Universitas Sriwijaya, Palembang, 2008.

Fahmal, H.A. Muin, Asas-asas Uimum Pemrintahan yang Layak dalam Mewujudkan Pemerintahan yang Bersih, UII Press, Yogyakarta, 2006.

HS, Salim, Tekhnik Pembuatan Akta Satu (Konsep Teoretis , Kewenagan Notaris, Bentuk, dan Minuta Akta), Rajagrafindo Persada, Jakarta, 2015.

Peraturan Menteri Hukum dan Hak Asasi Manusia Nomor 7 tahun 2016 Tentang Majelis Kehormatan Notaris.

Putusan Mahkamah Konstitusi Republik Indonesia Nomor 49/PUU-X/2012 atas Pasal 66 ayat (1) Undang-undang Jabatan Notaris.

Ridwan, Juniarso, dan Achmad Sodik Sudrajat, Hukum Administrasi Negara dan Kebijakan Pelayanan Publik, NUANSA, Bandung, 2010.

Sjaifurahman dan Habib Adjie, Aspek Pertanggungjawaban Notaris Dalam pembuatan Akta, Mandar Maju, Bandung, 2011.

Undang-undang Darurat Republik Indonesia Nomor 7 Tahun 1955 tentang Pengusutan, Penuntutan, dan Peradilan Tindak Pidana Ekonomi.

Undang-undang Nomor 31 Tahun 1999 yang telah diubah dalam Undang-undang Nomor 20 Tahuhn 2001 tentang Pemberantasan Tindak Pidana Korupsi.

Undang-undang Nomor 5 Tahun 1986 tentang Peradilan Tata Usaha Negara

www.indonesianotarycommunity.com

www.kbbi.web.id.

Zubair, Ahmad Charris, dimensi Etik dan Asketik Ilmu Pengetahuan Manusia: Kajian Filsafat Ilmu, Lembaga Studi filsafat Islam (LSFI), Yogyakarta, 2002. 